\title{
STYLISTICS: AN ANALYSIS OF ROALD DAHL'S GEORGE'S MARVELOUS MEDICINE AND THE GIRRAFE AND THE PELLY AND ME TO PROVIDE INSIGHTS ON ESTABLISHING WRITING STYLE
}

\author{
Debora Chaterin S., MAEd \\ English Education Department, Universitas Advent Indonesia, Bandung Barat \\ e-mail: deborachaterins@gmail.com
}

\begin{abstract}
This study aims to provide insights on establishing writing style through stylistic analysis on Roald Dahl's George Marvelous Medicine and The Giraffe and The Pelly and Me. This is a qualitative study which focuses on literary analysis. The data was collected from those two books. Evidently this study will bring benefit to English majors to gain insights on how to establish effective writing style. The findings of this study show that Dahl has four outstanding elements for writing style: Lead Sentences, Rhyme-schemed poem, Peculiar Chosen Words, and Concept of Personification. Although Dahl's books have great insight on establishing one's writing style, there are some positive and negative influence that should be considered in reading Dahl's masterpieces. The positive influence is
\end{abstract}

Keywords: Stylistics, elements of writing style, literary analysis

\section{INTRODUCTION}

English majors have possible careers in teaching, publishing, public relations, advertising, or media. A degree in English provides occupations to be considered, such as English teacher, copywriter, columnist, critic, editor, correspondent, technical writer or writer/author for non-profit organizations. Therefore, students who hold English degree should comprehend the statement of Hoover and Lattig (2007) regarding style of writing; where in, he states that learners should be knowledgeable in understanding usage of words to delve the potential effect of writers' message; they should know the style and language of poems, novels, and plays to draw upon the terminology and methodology of disciplines which focus on the fundamental units and principles of all linguistic usage, such as phonemes, rhythmic sequences, grammatical classes, forms of syntactic organization and so on. In addition, Ramet (2004) accentuated writers who have established their writing style own ability to showcase their potential by creating a written masterpiece. However beginner writers should consider that writing style cannot be established in one day; rather it should be establish naturally over time; in the long run, they will gradually learn how to blend a fiction world or fictional characters and how each paragraph is centralized with the narrative. 
To establish effective writing style, it can be seen through the telescope of stylistics. Stockwell and Whitely (2004) stated stylistics is the study of literary discourse which forms a linguistic orientation. It is part of linguistics which concentrates on variation in the use of language. Furthermore, Bradford, (2005) said stylistic is the study that has to do with making choices. Many kinds of professional writing aims for effective transfer of information. Furthermore, as stated by Simpson (2004), stylistics is considered to be a tool to explore language and creativity in language use; therefore, it is important for English majors to understand stylistics in order to establish their style of writing and make known their writings to public.

In order to provide insights on how to establish effective writing style, the writer utilized masterpieces of Roald Dahl. The reason behind choosing Roald Dahl's masterpieces is because he is known to be one of the world's most talented children's authors. The writer of this study took joy in reading his masterpieces. He was a British writer who was famous for his ingenious short stories and macabre children's book. He had written hundreds of books in his lifetime. He wrote books for children, teenagers, and adults. Many of his notable words had been made into movies, namely Willie Wonka and the Chocolate Factory, Matilda, Fantastic Mr. Frost, to name a few. Cullingford (2000) said that Dahl created his writing style to entice his readers. His stylistic way of writing is deemed to provide greater insights to establish one's writing style because it arises curiosity of his readers to read more of his writings. In addition, Gavins and Steen (2003) wrote that Dahl has ability to showcase his potential by creating intricate plot which somehow will always leave questions to his readers. Thus this study addressed the following questions:

1. What outstanding elements of style did Roald Dahl utilized in the stories entitled George's Marvelous Medicine and The Giraffe and The Pelly and Me that could be learned?

2. In establishing writing style, what are the pros and cons sides of Roald Dahl's books: George's Marvelous Medicine and The Giraffe and The Pelly and Me?

\section{METHODOLOGY}

This study is qualitative in nature. For this study, the writer analyzed and explored two books of Roald Dahl: George's Marvelous Medicine and The Giraffe and the Pelly and Me. To ensure the validity of the study, the writer read these two books thoroughly over and over and used stylistic analysis to produce effective results. The use of stylistics has been widely known to be effective in exploring creativity of a language (Simpson, 2004).

\section{Data Analysis}


Data were gathered from Dahl's books: George's Marvelous Medicine and The Giraffe and Me. The data were collected qualitatively. The followings were the procedure to collect the data:

\section{Planning Stage}

The first stage to seek answers of the research questions by reading the two books of Roald Dahl thoroughly, over and over.

\section{Data-gathering Stage}

Data were gathered from Dahl's two books. All data were categorized in order to find out outstanding elements of Dahls' writing style and also to seek positive and negative influence of Dahl's masterpiece. After gathering all the outstanding elements; the writer used them as evidence of analysis.

\section{Analysis Stage}

The evidence was analyzed using stylistic tools.

\section{RESULT AND DISCUSSION}

The results of the analysis are presented and discussed below. Data were taken from Dahl's two books: George's Marvelous Medicine and The Giraffe and the Pelly and Me.

\section{Dahl's Outstanding Elements of Style}

Through a careful analysis, it is found that Roald Dahl utilized different elements of writing style to entice his reader's attention:

Lead Sentences. One of outstanding elements of Dahl's writing style is Lead Sentence. Sanderson (2002) stated that writers might win or lose the reader with the lead sentence they created because as stated by it will describe what the whole paragraph is going to be about. Moreover, lead sentence is actually a topic sentence. Anderson (2006) added that it is imperative that the lead sentence of a story should catch reader's attention. Therefore in the story of George's Marvelous Medicine, Dahl started his stories with strong lead sentences as seen in the following excerpt:

I'm going shopping in the village. 'George's mother said to George on Saturday morning. 'So be a good boy and don't get up to mischief.' This was a silly thing to say to a small boy at any time. It immediately made him wonder what sort of mischief he might get up to. 'And don't forget to give grandma her medicine at eleven o'clock,' the mother said. Then out she went, closing the back door behind her.

Dahl arose questions in the minds of his readers through the word 'silly' and 'mischief'. It foreshadows the next scene which is going to happen. It is assumed 
readers would set in their minds that George must have been a mischievous boy who likes doing silly things around. His lead sentences hook his readers to continue reading the story.

While in the book of The Giraffe and the Pelly and Me, Dahl began the story not in a dialogue yet in a prosaic. Dahl's lead sentences in this book is a description of an old house. In describing the old house, Dahl inserted simple concept of Minimal Pairs like 'queer' and 'peer'. According to Bauman-Waengler (2008) Minimal pairs are often used by writers to excite interest of readers. Readers would sense peculiarity and uniqueness in Dahl's lead sentence; it serves as introduction of his story, as seen in the following excerpt:

Not far from where I live there is a queer old empty wooden house standing all by itself on the side of the road. I long to explore inside it but the door is always locked, and when I peer through a window all I can see is darkness and dust. I know the ground floor used once to be a shop because I can still read the faded lettering across the front which says THE GRUBBER.

From the two books, it is found that Dahl used different ways of presenting his lead sentences. He utilized direct discourse and prosaic as his lead sentences. Simply to say that Dahl did not focus only on one technique to create his lead sentences.

Rhyme-schemed Poems. Another element of Dahl's writing style is Rhymeschemed Poems. Dahl's ability to be playful with words is utterly shown in his way of writing poems which mostly utilized and appeared in his story books. His rhymeschemed poems are considered to be hilarious albeit they sound sadistic at times. This element adds a touch of wackiness to the stories. In the poem, George's Marvelous Medicine Dahl used a rhyme-schemed poems as seen in the following:

'so give me a bug and a jumping flea,

Give me two snails and lizards three,

And a slimy squiggler from the sea,

And the poisonous sting of a bumblebee,

And the juice from the fruit of the ju-jube tree,

And the powdered bone of a wombat's knee.

And one hundred other things as well

Each with a rather nasty smell.

I'll stir them up; I'll boil them long,

A mixture tough, a mixture strong,

And then, heigh-ho, and down it goes

A nice big spoonful (hold your nose)

Just gulp it down and have no fear.

"How do you like it, Granny dear?" 
Will she go pop? Will she explode?

Will she go flying down the road?

Will she go poof in a puff of smoke?

Start fizzing like a can of coke?

Who knows? Not I. Let's you and see.

(I'm glad it's neither you nor me)

Oh Grandma, if you only knew

What I have got in store for you!'

The poem above sounds scintillating. Dahl creatively wrote the poem, a wonderful idea that should be admired by his readers. The poem above depicts how blithe George is with his new idea about the magic medicine for his horrified grandmother. Dahl utilized several words that have the same rhymes at the end of the sentence. From line one up to line six the rhymes are similar, such as flea, three, sea, bumble, tree, knee and from line seven and eight the same rhyme: well and smell. Line nine and ten has these rhymes, long and strong. The next lines, eleven and twelve, have almost similar rhymes: go and nose. Then line thirteen and fourteen has the same rhyme, fear and dear. The following is the poetic style, as it is shown below:

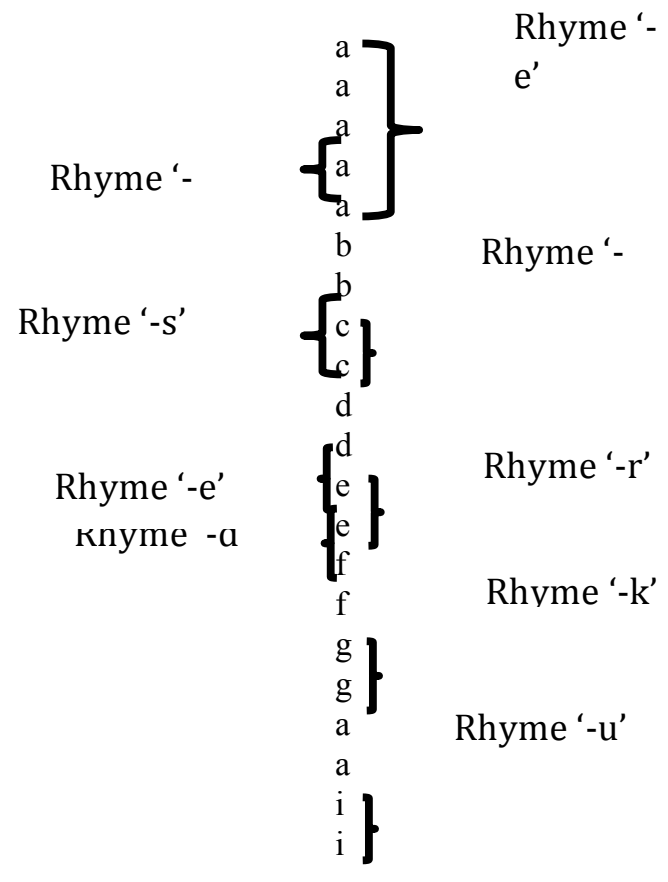

Whilst the poem, in the other story of The Giraffe and the Pelly and Me, sounds like Ballad yet it is not a ballad poem because Ballad means a short narrative poem with stanzas of two or four lines and usually a reference. It is written in straight-forward verse, seldom with detail, but always with graphic simplicity and force. Most Ballads are suitable for singing and while sometimes varied in practice. Dahl used sound-like- 
ballad poem to depict a cheerful Pelican bird that loves singing. The following is the song of the Pelican bird composed in a rhyme-schemed poem:

$\begin{array}{ccc}\begin{array}{cc}\text { 'Oh, how I wish } \\ \text { For a big fat fish! }\end{array} & \mathrm{a} & \\ \text { I'm as hungry as ever could be! } & - & \mathrm{b} \\ \text { A dish of fish is my only wish! } & \mathbf{-} & \mathrm{a} \\ \text { How far are we from the sea?' } & \mathbf{-} & \mathrm{b}\end{array}$

The above poem has a-a-b-a-b scheme. The first, second and fourth line have the same rhyme scheme: wish, fish, wish. And the fourth and the las stanza have the same rhyme scheme: be and sea. Hence, the researcher described this song poem in a poetic style. Another poem that the researcher found in the story of The Giraffe and the Pelly and Me is shown below:

$$
\begin{aligned}
& \text { 'So I slide it away } \\
& \text { For the rest of the day! } \\
& \text { Even so, I'm still able to speak! - b } \\
& \text { And wherever I've flown } \\
& \text { It has always been known } \\
& \text { As the Pelican's patented beak! -b } \\
& \text { If I want to eat fish } \\
& \text { (That's my favorite dish) } \\
& \text { All I do is I give it a weak! - b } \\
& \text { In the blink of and eye } \\
& \text { Out it pos! and they cry, } \\
& \text { It's the Pelican's Patented Beak!' - b }
\end{aligned}
$$

The above poem is a dialogue of the cheerful Pelican in the story. In the story of The Giraffe and the Pelly and Me, Dahl showed his love towards rhyme-schemed poems which definitely grasp the attention of his readers.

Peculiar Chosen Words. To enhance his writing style, Dahl provided vivid description in his stories by using peculiar choice of words. The following are the categories of his interesting choice of words:

Compounding. To attract young readers to relish his story, Dahl used Compounding and principles as one of his writing style elements. Compounding is a principle to combine two of more free morphemes to form new word thing (Fisher, Kemenade, Koopman, \& Wurff, 2004). The following evidence is taken from the story of The Giraffe and the Pelly and $\mathrm{Me}$ : 
Then the sweets and chocs an toffees and fudges and nougats began pouring in to fill the shelves. They came by aeroplane from every country in the world, the most wild and wondrous things you could ever imagine. There were Gumtwizzler and Fizzwinkles form China, Frothblowers and Spitsizzlers for Africa, Tummyticklers and Gobwangles from the Fiji islands and Liplickers and Plushnuggets from the land of the Midnight sun.

Words that are compounded by Dahl are Gumtwizzler (Compounding 'Gum' and Twizzler), Frothblower (Compounding 'Froth' and 'Blower'), Spitsizzler (Compounding 'Spit' and 'Sizzler'), Tummytickler (Compounding 'Tummy' and 'Tickler), and Liplicker (Compounding 'Lip' and 'Licker'), 'Gobwangle' (Compounding 'Gob' and 'Wangle'), and 'Fizzwinkle' (Compounding 'Fizz' and 'Winkle'). All the words compounded have particular definitions and meanings to spice up the story. The following is the analysis of Dahl's compounding words:

Gumtwizzler. Roal Dahl chose the word 'gum' which means sticky substance to chew; it is part of sweet. And he added the word 'twizzler' to give strong definition to his compounding word. The word 'Twizzler' means a popular brand of fruit-flavored candy in the United States and Canada (often called a licorice candy). It is known to be the product of $\mathrm{Y} \& \mathrm{~S}$ Candies, Inc., of Lancaster, Pennsylvania, now a subsidiary of the Hershey Company. Fizzwinkles. Dahl chose the word 'Fizz' which means an effervescent beverage, and the word 'Winkle' means edible sea snails. He combined these two words to provide emphasis on children's delicacy. Young readers who read this story might have an idea that this liquid sweet is in a form of snail. Frothblower. Dahl used the word 'froth' that means collection of small bubbles or other definition defines 'froth' as things to cover something with foam and compound it with a word 'blower' which means to drive air upon or into. Hence 'Frothblower' means sweet bublle that children could blow. Tummytickler. Dahl used the word 'tummy' which means stomach and partner it with a word 'tickler' which comes from the word 'tickle' which means to produce laughter. Therefore the readers might picture in their minds that 'Tummyticklers' is a type of food that could make the tasters laugh or this is a food which might tickle the tummy of the eater.

Gobwangle. Dahl chose the word 'Gob' - taken from the word 'Gobble' which means eat noisily or greedily. And the word 'wangle' means to get something in a devious way. Roald Dahl might aim to describe type of food which could increase children's appetite to eat more and more.

Liplicker. Dahl chose the word 'lip' which means the edge of the mouth and the word 'Licker' which comes from the word 'lick' that means pass tongue 
over. The word 'Liplicker' is a type of food that will taste better on the lips of the taster.

Plushnuggets. Dahl used the word 'plush' which means luxurious and partner it with a word 'nugget' which means something small but valuable or nowadays it is known as delicacy in meat. Hence the word 'Plushnugget' might mean luxurious delicacy for children.

The way Dahl compounded his words creates impressive imaginary. This is a style that English majors should learn in enhancing their writing skills.

Onomatopoeia. In Dahl's chosen words, Onomatopoeia is used. It is one of his ways to kindle his readers' minds. Onomatopoeia means word that sounds made by particular objects (. . .); it is a words that imitates harmony. It provides full flavor of words (. . .). Onomatopoeia is classified into two: Nonlexical and Lexical onomatopoeia. Non-lexical is a word in a form of sound while Lexical Onomatopoeia is a sound which is formed into a word. After a careful analysis, evidence is seen below from the story of George's Marvelous Medicine:

' ... so you've got to bite the earwig first, chop-chop, before it bites you.' (p. 8 line 16). The word 'chop-chop' is a Lexical onomatopoeia.

'Grandma yelled, "Oweeeee!" and her whole body shot up Whoosh into the air. (p. 39 line 20). In this excerpt, there are two non-lexical onomatopoeias 'Oweeeee' and 'Whoosh'

'Crash! The old girl's head went through the ceiling as though it were butter. (p.47 line 23). The word 'Crash' in this excerpt is considered to be non-lexical onomatopoeia even though it can be also used as lexical onomatopoeia.

'Come on, chicken,' George said. "Good Chicken. Chick-chick-chick." (p.53 line 8). The word 'chick-chick-chick' is non-lexical onomatopoeia to give effect of the chicken's movement.

'The broken hen stretched out its neck towards the spoon and went peck. It got a beakful of medicine (p. 53 line 10). The word 'Peck' is a Lexical onomatopoeia; it is a sound of bird biting its food.

'While he was doing this, the big brown hen sat down in the middle of the yard and went 'cluck . . . cluck. . . cluck. . . cluck-cluck-cluck-cluck.' (p. 61 line 15). The word 'cluck' is non-lexical onomatopoeia. It gives imaginary of the sound of hurriedly walking hen. 
'Then sparks came flying out of its beak, bright yellow sparks of fire, as though someone was sharpening a knife on a grindstone inside its tummy.' (p. 82 line 6). The word 'Spark' is a Lexical onomatopoeia; it gives imaginary of the sound of flame.

'Cock-a-doodle-do!' squawked the cockerel, shooting up into the air and coming down again.' (p. 86 line 11). The 'Squawk' is a Lexical Onomatopoeia which means to make a loud noise.

“'Ouwch!” it said, then a funny whistling noise came out of its beak.' (p. 90 line 1) The word 'Owch' is a Non-lexical Onomatopoeia. It gives imaginary of the sound of injured bird.

From the above evidence, it shows that Dahl is fond of using Onomatopoeia in narrating his stories to make it more powerful and colorful. In the other story of The Giraffe and the Pelly and Me, Dahl also incorporated Onomatopoeia, both lexical and non-lexical. The followings are the evidence:

'Whoopee! The monkey became delightful'. (p. 26 line 16) The word 'Whoopee' is a Non-lexical Onomatopoeia. It gives imaginary of the sound of a delightful monkey.'

'Suddenly there was an ear-spliting bang and the Pelican leaped twenty feet into the air. So did the Duke. (p. 48 line 1). The word 'Bang' is a nonlexical onomatopoeia; it gives imaginary of the sound of falling objects.

There was not much onomatopoeia in the story of The Giraffe and The Pelly and Me. Dahl used more on word pictures in expressing sound. Through word picture, onomatopoeia is built in the minds of the readers. Sanderson (2002) sated that word pictures show readers the character, action, and setting. The following is the word picture which contain onomatopoeia.

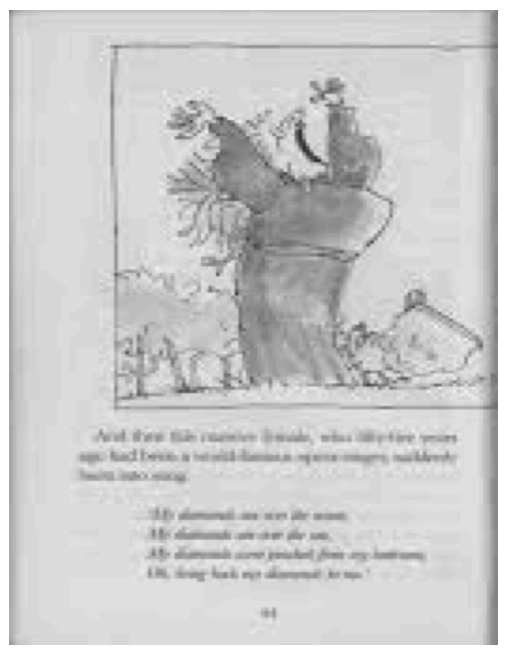


Dahl used word picture to describe the illustration of a screaming lady.

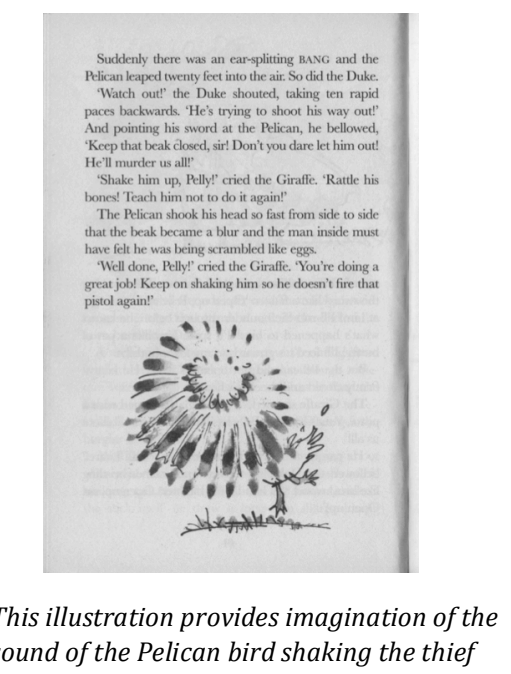

Descriptive adjective. Dahl makes use of descriptive adjectives to provide vivid details about his character and the situation. His descriptive adjectives his lenses to allow his readers to imagine and infer characteristic of his characters, instead of directly telling the readers (Cullinan, 2005). Some of descriptive adjectives used are mainly to describe the sense of touch to bring about the emotional state of the characters; it is also to describe physical appearance to show the exact emotional of the characters. It is evidently shown in the following excerpt, taken from George's Marvelous Medicine:

'She was selfish grumpy old woman. She had pale brown teeth and a small puckered-up mouth like a dog's bottom.' (p.2 line 11, 13)

The above excerpt is a description of George's grandmother. Dahls shows his readers vivid appearance of how George's grandmother looks like. Another evidence of Dahl's descriptive adjectives, forming some nouns as modifiers, is the following excerpt:

'bathroom items: golden gloss hair shampoo, toothpaste, some shaving soap, vitamin-enriched face cream, nail varnish, hair remover ('smear it on your 
legs'), brillident (for cleaning false teeth), dishworth's famous dandruff cure, nevermore ponking deodorant spray and liquid paraffin.

'bedroom items: Helga's hair set, "flowers of turnips" (it smells like old cheese), pink plaster face powder and a powderpuff and lipstick.'

laundry room items: superwhite (for automatic washing machines), waxwell floor polish, flea powder, canary seeds and dark tan shoe polish.

'kitchen cupboard: curry powder, mustard powder, a bottle of extra hot chilli sauce, a tin of black peppercorns and a bottle of horse radish sauce.'

'shed items: chicken medicine, horse strength throat lozenges, cow ointment, sheep dip and pig pills.

'garage items: engine oil, anti-freeze and a handful of grease.

'also: bottle of gin, one quart dark brown gloss paint (for color) and petrol.

Dahl used animal image to be his descriptive adjectives to accentuate sense of humor. It is assumed to evoke readers' curiosity on what is going to happen in the next scene.

Concept of Personification. In both of his books: George's Marvelous Medicine and The Giraffe and the Pelly and Me, Dahl incorporate image of animals. The animals in the story portray special characters that bring great impact to the stories; those animals are portrayed to have humanlike minds. His way of transforming animals to personify humans is termed as personification. Quinn (2012) stated that personification an ontological metaphor in which a thing or abstraction is represented as a person. The use of animals is to bring closer the gap of the characters to his young readers.

Dahl's George's Marvelous Medicine and The Giraffe and the Pelly and Me has indeed provided deep insights on establishing one's writing style. It is believed to be beneficial to English majors or beginner writers to enhance their writing skills. Therefore there are positive influences that readers should consider:

Picturesque Narration. Dahl's writings provide positive influence that could be obtained. He provides insights on creating fictional yet alive characters. It opens one's mind to be creative in narrating the stories. He or she might learn to create peculiar words to give strong impact to their readers. He is using concept of 'Showing' instead of 'telling'.

Room of Imagination. Dahl is expert in giving room for his young readers to imagine, think, and wonder. Through such a style, once again, Dahl 
is able to enchant his readers. This definitely contributes insights on how to create rich plots of a story, making imaginary seem real. Although some of Dahl's narrations are sarcastic, his readers could sense moral lessons.

However readers should consider negative influence that might occur by reading Dahl's masterpieces:

Sarcastic Tone. One obvious trait in Dahl's Masterpieces is the use of devilish twists and turns. This twist brought into the story actually grasped readers' attention. His humor is also known for his risqué outrageous comments about things not normally mentioned in children's story books (Sanderson, 2009). Therefore English majors should be aware of emphasizing their tone.

Alteration of Standard. To some, his stories might give stereotypical impression which lead his readers to grasp wrong ideas on a particular standard. For example in the book of George Marvelous Medicine, it gives ideas that the young could treat the old badly. It is somehow a dangerous act if readers follow what the main characters do. For readers who dislike their grandmothers they might want to give horrible medicine to their grandmothers; this might alter the real standard of life. Indeed Dahl's might somehow introduce his readers to fantastic creatures and bizarre places which encourages readers' imagination to run wild. Therefore English majors who desire to establish their writing style should wisely narrate their stories by not altering the standard of life.

\section{SUMMARY AND CONCLUSION}

Writing style can be established through reading variety of books. Reading some masterpieces of Roald Dahl can provide deeper insights on how to establish writing style. Dahl has the power to create, narrate and show his imagination in his masterpieces. He had inexplicable and astonishing talents in writing. He had brought huge impact towards his readers, by allowing his readers to express different levels of thinking. It is one of successful key to establish writing style. From this study, it is found that Dahl utilized four outstanding elements of style: Lead Sentences, Rhyme-schemed Poem, Peculiar Chosen Words, and Personification. These elements are to be regarded by English majors as way of establishing writing style. However there are positive and negative influence that should be considered in reading Dahl's writing. Dahl provides positive influence in his masterpieces; his 
narration is picturesque; it hooks his readers to continue reading the story. Aside from that, Dahl also provide room of Imagination for his readers. He is able to empower his readers to have greater imagination of the characters and story setting. Yet Dahl's masterpieces somehow might give negative influence. One of the mostly known negative influence is his sarcastic tone and Alteration of Standard. Readers should be smart and wise in segregating the negative influence. Therefore the researcher concludes that to establish writing style, a person must first establish for reading variety of writings as stated by (Barr et.al., 2007) After establishing passion for reading, a person should learn to analyze pieces of writing using concepts of stylistics. 


\section{REFERENCES}

Anderson, L. (2005). (Eds). Creative writing. Routledge.

Barr, et al. 2007. Reading diagnosis for teachers: an instructional approach. Pearson: National-Louise University.

Bauman-Waengler. Introduction to Phonectics and Phonology from concepts of transcription. Pearson Beard. R.

Brandon, R. (2004) Ed. The little red writing book (Edited by Jane Friedman). Writer's Digest.

Cullinan, B.C., (2005). The continuum encyclopedia of children's literature. Continuum Publishing Company.

Cullingford, C. (2000) Eds. Children's Literature and its effects. York House.

Fisher, O., Kemenade, A.V., Koopman, W., Wurff, W.V. (2004). The syntax of early English. Cambridge.

Gavins, J \& Steen, G. (2003) Ed. Cognitive poetic in practice. Routledge.

Hoover, D.L \& Lattig, S. (2007) Ed. Stylistics: prospect and retrospect. Rodopi: Amsterdam.

Langosch, S.L (2004). Wriitng American style on ESL/EFL. Handbook. Barron's.

Ramet, A. (2004). Creative writing: how to unlock your imagination, develop your writing skills, and get published ( $5^{\text {th }}$ Ed.). How to Books, Ltd.

Simpson, P. (2004). Stylistics: A resource book for students. Routledge.

Stockwell, P. \& Whiteley, S. (20014) Eds. Stylistics. Cambridge University Press.

Quinn, A. (2012). Figures of speech: 60 ways to turn a phrase. Routledge.

Wright, L. \& Hope, J. (2005). Stylistic: A practical course book. Routledge. 